\title{
IMPLEMENTATION OF NATIONAL AND REGIONAL POLICIES FOR DEVELOPMENT OF SOCIAL ENTREPRENEURSHIP IN BULGARIA
}

\author{
Venelin Terziev ${ }^{1}$ and Marin Georgiev ${ }^{2}$
}

${ }^{1}$ Academician of the Russian Academy of Natural History, Moscow, Russia, Prof. D.Sc. (Ec.), D.Sc. (National Security), D.Sc. (Social Activities), Ph.D., National Military University, Veliko Tarnovo, Bulgaria; University of Rousse, Rousse, Bulgaria, terziev@skmat.com

${ }^{2}$ Ph.D., National Military University, Veliko Tarnovo, Bulgaria, clementon@abv.bg

\begin{abstract}
The practice of member states of the European Union with a developed social economy shows that it should be given a legal definition of the social enterprise in which preponderance to be no regulation in what form it will be organized as a subject of law but on what goals it sets and what effects are pursued. The leading role in this process should be given to a clear identification of the social benefit of the activities of the social enterprise with specific dimensions of lasting social impact to persons with disabilities. It is necessary the legal definition to encourage the development of various entrepreneurial initiatives with social impact, not limiting social enterprises to only one legal form.
\end{abstract}

Keywords: implementation, national policies, regional policies, development, social entrepreneurship, EU.

\section{INTRODUCTION}

Bulgaria, as a member of the European Union accepts and follows EU policies in the field of social enterprise and entrepreneurship:

EC purposefully and consistently work on developing a policy framework for the social economy and social entrepreneurship in the EU. The ESC welcomes these efforts and found that they seriously affect the development of social economy in the country. Extremely important role of social enterprises and social entrepreneurship in the country and contribute to the EU development and implementation of a number of key documents such as:

- The Commission Communications' Social Business Initiative - Creating a favorable environment for social enterprises, key stakeholders in the social economy and innovation and Towards recovery and job creation;

- Single Market Act I: Twelve priority measures to promote growth and strengthen confidence", one of which relates to the promotion of social entrepreneur-ship;

- Single Market Act II - Together for new growth; 
- The European Parliament resolution on the Social Business Initiative;

- Special Report from the Committee from 2012 - The social economy in the European Union, which updates a similar report released in 2008. It examined the state contribution, legal instruments and public policies relating to the social economy and its role to overcome the economic crisis.

Other strategic documents relating to social enterprises and social entrepre-neurship are:

Strategy "Europe 2020" where Priority 3 reads achieve "inclusive growth, which will stimulate the economy with high employment levels, leading to social and territorial cohesion".

EC Communication "Social Business Initiative - Creating a favorable climate for social enterprises, key stakeholders in the social economy and innovation", which outlines an action plan to promote social entrepreneurship in Europe in three main ar-eas:

- The first strand is aimed at facilitating access to private funding and mo-bilize European funds to support the financing of social enterprises. This is expected to encourage private and public stakeholders to invest more of its capital or loans for social enterprises.

Following adoption of this key action, the Commission proposed the creation of a Regulation on European Social Entrepreneurship Funds, which was adopted by the EP and the Council of 17 April 2013, and the Programme for Social Change and Innovation. The program provides for the creation of a European financial instrument amounted to $90 \mathrm{mln}$. Euros, which will facilitate access to finance for social enter-prises to start up their business, its expansion and development.

- The second direction is to strengthen awareness of social entrepreneur-ship by developing appropriate tools. In this direction is the creation of a national da-tabase of social enterprises in the country.

- The third direction is connected with the improvement of the legal envi-ronment for social entrepreneurship by providing the Commission to clarify the legal forms that can be used by social entrepreneurs and to facilitate social enterprises' ac-cess to public procurement.

European Employment Strategy is designed in accordance with the strategy "Europe 2020" to help create throughout the European Union (EU) more and better jobs. The strategic objectives in support of this are:

- To give "new impetus", involving all stakeholders and strengthen controls on national agreements combining flexibility and security of employment;

- Develop self-employment.

Action Plan "Entrepreneurship: 2020 revival of entrepreneurship in Europe", drawn up in 2013 and outlines the steps for decisive joint actions to unleash the en-trepreneurial potential by removing existing barriers and implement radical changes in the entrepreneurial culture in Europe. There are immediate actions in three areas:

- The first is education and entrepreneurship training in two main direc-tions - increasing the range and quality of entrepreneurship education and higher edu-cation in entrepreneurship.

- The second area of action is to create a favorable environment for the growth and development of businesses by removing obstacles that hinder their crea-tion and development; access to financing; support during the crucial stages of the life cycle and growth of enterprises; deployment of new business opportunities offered by digitization; An easier transfer of ownership of enterprises; review the procedures for bankruptcy and providing a second chance for honest entrepreneurs insolvent; reducing the regulatory burden.

- The third area of action refers to measures to promote entrepreneurs as role models for entrepreneurship and inclusion of women, the elderly, migrants, the unemployed and young people.

Regulation of the European Parliament and of the Council on European Social Entrepreneurship Funds from April 17, 2013. It should support the market for social enterprises through more effective fundraising by investment funds that are oriented to those companies. It provides for the creation of a European Social Entrepreneur-ship Fund as a collective investment undertaking which aims to invest at least $70 \%$ of its aggregate capital contributions and uncalled committed capital in assets that are qualifying investments.

Social enterprises and social entrepreneurship are facing a number of challeng-es related to their better visibility, creating a more favorable legal and institutional environment for their operation, as well as providing better financial opportunities for their development. 
The Economic and Social Council (ESC) of Bulgaria recommends setting up a single European definition of social enterprise, which become the basis for plans of legal action by the constitution of social enterprises in the country. According to ESC, required explicit recognition by the public authorities of the different identity of these organizations. ESC considers necessary improvement of cooperation horizontally (between social enterprises) and vertically (between social enterprises and public in-stitutions) level.

Considering that the social economy has a substantial capacity for social inno-vation, the ESC insists that social enterprises are further encouraged in their efforts to find innovative solutions to social problems (eg. The reconciliation of work and pri-vate life, gender equality, the quality of family life and ability to care for children, the elderly and people with disabilities).

One of the latest innovations in the social sphere is the concept of "Experts from experience," developed precisely as a form of social entrepreneurship. These are individuals with specific expertise acquired through personal experiences and exper-tise in social exclusion. The initiative aims to build on existing best practice in Europe to tackle social exclusion by introducing a qualitatively different approach to working with vulnerable groups by creating a profession "expert by experience" (Terziyev, 2019; Terziev, Bencheva, 2019a; Bencheva, Stoeva, Todorova, 2018; Bencheva, Tepavicharova, 2016; Tepavicharova, Bencheva, 2016a; Bogdanova, 2018a; Terziev, 2019b-c; Terziev, Bekiarova, Georgiev, 2019d; Bencheva, Stoeva, 2019e).

\section{LEGISLATIVE PROVISIONS}

In recent years there has been a clear European policy to promote social entrepreneurship as a key tool to tackle the challenges facing vulnerable groups or solve social issues, including replace (or displace) the traditional forms of social support (social services and payments). More and more funds from the EU budget is spent on concrete measures to support social enterprises. Only predictable budget of the Programme for Social Change and Innovation 2020 amounted to $€ 960$ billion - program, one aim of which is to support the development of social enterprises in the EU (2019h) This program will act together with the other EU instruments to provide funding in this area (European Social Fund, funds to support social enterprises and so on.).

In most Member States have chosen approach of explicit regulation, thereby encouraging develop specific policies.

European legislation provides a sound basis for the social economy. Relevant provisions contained in: Treaty on the Functioning of the European Union; Charter of Fundamental Rights of the European Union; Regulation (EC) № 1435/2003 of the Council of 22 July 2003 on the Statute for a European Cooperative Society; Directive 2003/72 / EC of 22 July 2003 supplementing the Statute for a European Cooperative Society with regard to the involvement of employees; Directive 2006/123 / EC of the European Parliament and of the Council of 12 December 2006 on services in the internal market; Council Decision 2008/618 / EC of 15 July 2008 on guidelines for the employment policies of the Member States; Commission Communication of 30 January 2008 on the proposal for the Joint Report on Social Protection and Social Inclusion 2008 (COM (2008) 0042), accompanying document to the Commission Communication on the proposal for a joint report (SEC (2008) 0091) and to the joint employment report for 2007-2008, endorsed by the Spring European Council of 13-14 March 2008 .; Resolution of 6 May 1994 concerning alternative social economy; EP resolution of 18 September 1998 on the role of cooperatives in the growth of women's employment; EP resolution of 17 June 2008 on the proposal for a Decision of the European Parliament and of the Council concerning the European Year for Combating Poverty and Social Exclusion (2010); EP resolution of 23 May 2007 on promoting decent work for all; Resolution of 9 October 2008 on promoting social inclusion and combating poverty, including child poverty in the EU, as well as in a number of Communications of the European Commission; European Parliament resolution of 19 February 2009 on Social Economy (2008/2250 (INI)); European Parliament resolution of 20 May 2010 on a new partnership for the modernization of universities - dialogue between universities and businesses (2009/2099 (INI)).

Critical components of the legal analysis and development of proposals for legislative changes is the question of legal recognition of companies and organizations from the social economy as real and legally protected participants in economic processes. It is useful to bear in mind the European position expressed by the European Parliament (A6-0015 / 2009).

- Recognition of European statutes for associations, mutual societies and foundations required to ensure equal treatment of social economy enterprises in the internal market;

- The EP calls on the Commission and Member States to develop a legal framework that recognizes the social economy as a third sector; 
- Calls on the Commission to ensure that the European private company will be a company that can be adopted by all types of businesses;

- Calls on the Commission to set clear rules to be established which entities can legally operate as social economy enterprises and to introduce effective legal barriers to entry so that only social economy enterprises can benefit from funding designed for social economy enterprises or from public policies designed to encourage social economy enterprises;

The European Parliament (Decision A6-0015 / 2009)

- urges the Commission and Member States to support the social economy, to establish national satellite accounts for each institutional sector and branch of activity and allow for this data to Eurostat, also by making use of universities;

- points out that evaluation of the social economy is closely linked to the assessment of non-profit organizations, calls on the Commission and Member States to promote the use of the UN Handbook on nonprofit organizations and to prepare satellite accounts which will improve the visibility of organizations nonagricultural aim.

On this basis the Commission develop and guide the establishment of satellite accounts for social economy enterprises. The purpose of these satellite accounts is greater statistical visualization of these undertakings with regard to their specific social role.

The need for statistics on enterprises whose activity is not directed entirely and solely for profit, and to achieve social objectives, such as profit is reinvested in whole or in large part to achieve these goals will become more relevant in context of the implementation of the renewed Lisbon strategy 2020, aimed at developing a "social market economy". The creation of statistical databases such enterprises, their maintenance and updating necessary. With this concept states that need and provides for the creation of such a database at the Ministry of Labour and Social Policy. The aim is to determine the number of social enterprises at home and their employees from disadvantaged groups, and create on this basis a mechanism for monitoring the activities of social enterprises. The National Statistics Institute is expected to cooperate as a page publish the link to the statistical database to MLSP for social enterprises on the basis of an agreement.

From the analysis of EU policy documents can be identified two interrelated lines of the common European policy towards social enterprises:

- Increasing legal regulation to standardize understanding of what social enterprise and

- Planning and allocation of financial resources towards creating and sustainable social enterprises.

Thus ensuring on the one hand a clear basis, criteria and limited scope for implementing support measures of any kind - financial and non-financial - on the other hand does not lead to accumulation of regulation and regulatory burden without further support.

Bulgarian national legislation also provides comprehensive legal framework for the development of activities that have their reference to the characteristics of the social economy: Trade Law; Law on Cooperatives; Law for Non-Profit Organizations; Law for the integration of people with disabilities; Law on Employment Promotion; Social Assistance Act; Law for SMEs; Crafts Act; Law on Protection and Development of Culture; Law on Corporate Income Tax.

According to Art. 316 of the Labour Code, municipal councils are obliged to create specialized municipal enterprises and employers with more than 300 employees - workshops and other departments for persons with permanent disability, the activities of specialized enterprises is planned and accounted for separately.

Municipal councils can create municipal enterprises:

- By commercial companies with municipal shareholding registered under the Trade law;

- By municipal corporations established under the Municipal Property Act.

In the current legislation the term "enterprise" is not clearly defined. Various laws give their self-definitions intended solely for the purposes of their own regulation. The Trade Law defines a commercial "enterprise" as a set of rights, obligations and factual relations of a merchant. According to the Law on Protection of Competition "undertaking" means any natural or legal person or partnership that carries on business in the relevant market, regardless of its legal and organizational form. Under the Law on State Aid "undertaking" means any natural or legal person or partnership that carries on business, regardless of ownership, legal 
and organizational form. According to the Small and Medium Enterprises "undertaking" means any individual trader according to Art. 1 of the Trade law and craftsmen under the Crafts Act.

In tax law the concept is defined as broadly as possible in order to ensure fiscal interests of the state. For tax purposes Law on Corporate Income Tax Act deals with the concept of "place of business", which is definitely room basis or permanently any commercial transactions in the country. According to the Income Tax Act of individuals 'undertaking' is an undertaking within the meaning of the Accounting Act, which defines enterprises as:

- Traders under the Trade law;

- Legal persons who are not traders, budget enterprises, unincorporated associations and foreign persons conducting business in the country through a permanent establishment.

Legislation governing the status and regulates the activity of social enterprises in the country is underdeveloped. In Bulgarian legislation there is no legal definition of social enterprise, and rules governing the status, form and activities of the social enterprise. Moreover, the term "social enterprise" does not exist formally in the legislation of the country.

The only legislative regulated enterprises are specialized enterprises and cooperatives of people with disabilities.

According to the Integration of Persons with Disabilities specialized enterprises and cooperatives of people with disabilities are those who fulfill the following conditions:

- Have been registered under the Trade Law or the Law on Cooperatives;

- Produce goods or provide services;

- Have a share of persons with disabilities as follows:

Specialized enterprises and cooperatives for the blind and partially sighted persons - not less than 20 per cent of the total number of staff;

Specialized enterprises and cooperatives of people with hearing impairments - not less than 30 percent of the total number of staff;

Specialized enterprises and cooperatives of persons with other disabilities - not less than 50 per cent of the total number of staff.

- Entered in the register kept by the Agency for Persons with Disabilities.

- Under the Public Procurement Act specialized enterprise or a cooperative of persons with disabilities is what:

- Is registered under the Trade Law or the Law on Cooperatives;

- There are a total headcount of less than 10 people;

- produces goods or provides services and

- No less than 50 per cent of the total number of employees are persons with disabilities.

Patterns of social enterprises in Bulgarian practice

Social enterprises in Bulgaria operate in several directions:

Delivery of social services;

Providing jobs for people with disabilities;

Mediation in finding employment of unemployed persons;

Provision of health services;

Activity in the field of education and others.

One of the most outstanding areas of work of the Bulgarian social enterprises is the delivery of social services. This became possible after the conducted reforms in the social sphere in 2003 with amendments to the Social Assistance / SAA / and its implementing Rules. The provisions of the law regulating the circle of persons capable of being designated to provide necessary services, it is not proposed comprehensive range of subjects, and are described with the following features - the state, municipalities, Bulgarian physical 
persons registered under the Trade law and legal entities, individuals carrying out commercial activities and legal entities arising under the laws of another state - member of the European Union or another country of the European economic Area. And here the emphasis is not on the legal form of social enterprise, but on this activity is to support individuals and leads to social inclusion within the meaning of the SAA. Together, we must emphasize the need to develop social entrepreneurship outside the narrow confines of the provision of social services.

In pursuance of national policy in the social state delegate the performance of certain functions of the mayors of the municipalities in Bulgaria, as in turn give them the right to dispose of the funds for this by themselves means are provided and translated based on the state budget each calendar year. Mayors reserve the right to supplement designated by the state to local activities, providing them with funding by the respective municipal budget. Bulgarian legislation expressly provides for t. Pomegranate. Socio negotiation assigning social services financed by public funds to private providers. This is done through a competition organized by the Mayor of the municipality or the terms of negotiation involving the sole candidate. The control over the legality of the procedure may be exercised by administrative order in front of the customer or by court order before the administrative court. The law provides for the possibility provider of social services to provide these services alone against the agreed remuneration on market principles. The degree to achieve quality in the service appears:

- Compliance with the criteria and standards set by the regulations to implement the SAA and the ordinance on criteria and standards for social services for children adopted by the Council of Ministers of the Republic of Bulgaria;

- Required by law special registration to the Agency for Social Assistance /ASA/ and the State Agency for Child Protection in cases where beneficiaries of social services are children.

- One of the regulations envisaged opportunities for development of social entrepreneurship is reflected in the Law for Integration of Persons with Disabilities /IPDA/. This approach of the legislator is different manifestation being placed focus on two main criteria by which to accept an ongoing concern as socially. The criteria are:

- Requirement of IPDA specialized enterprises and cooperatives of people with disabilities are registered in a particular legal form;

- Cooperatives should carry out activities related to the production of goods or provision of services, among employees should have a share of persons with disabilities.

Particular attention causes restriction of the law social enterprise occur in the form of commercial legal entity established under the Trade law or the Cooperatives Act. So now an enterprise can exist as a joint venture, limited liability company, limited partnership, limited partnership shares, and partnership, as well as cooperative. Practically more used forms are joint venture or limited liability company and with this in mind that capital companies to clearly distinguish the amount of liability.

- Alternatively, registration of social enterprise is a cooperative of disabled people covered under the Cooperatives Act. For its occurrence is sufficient declaration of intention at least seven individuals. IPDA does not clarify whether the very founders / members / and how many of them should be tied to membership in the cooperative relationship. The second requirement is that social enterprise is engaged in the production of goods or the provision of services, making it an active participant in the economy. In addition to that introduced quantitative dimensions of staff as follows, according to art. 28, para. 1 pt. 3 - for specialized enterprises and cooperatives for the blind and partially sighted persons - not less than 20 percent of the employee number;

- Specialized enterprises and cooperatives of people with hearing impairments - not less than 30 percent of the employee number;

- Specialized enterprises and cooperatives of persons with other disabilities - no less than 30 percent of the employee number.

In so set laws can conclude that the presence of the required legal form and economic criteria must be met cumulatively. To complete factual giving legal status to a union as a specialized enterprise for people with disabilities it is compulsory to fit in the Agency for Persons with Disabilities. Social enterprise registered under the IPDA, benefiting from more favorable treatment under Bulgarian legislation. However, it should consider further opportunities and those companies to gain a clearer status and financial and economic incentives, as and their stay in the market is associated with many challenges in the market. 
The activity of social enterprises in the field of health services is relatively limited, confined mainly to the guidance of some patients what type of health insurance rights and obligations are, and offering free-hold medical examinations, free distribution of drugs and devices not requiring specialized prescription.

According to the main law in this area - Health Act - health care facilities are structures of the national health care system in which medical and non-medical specialists carry out activities to maintain and strengthen citizens' health. Although satisfy some of these traits, social enterprises not having the status of a health establishment cannot provide health services and should limit their activity to that.

Social enterprises in the health sector achieve the desired social impact or limit its sphere of activity to the extent permitted, without the need for special registration under Hospitals law or register as a separate company or a cooperative in accordance with legal requirements. Unfortunately, the Bulgarian legislator has not provided the opportunity the legal form of medical institutions to NGOs, which actually deters many organizations - social enterprises to offer integrated health and social services for vulnerable groups.

\section{Legal form of social enterprises}

The most frequently chosen form that unites people to achieve certain goals in the social sphere is a legal non-profit entity under the Non:

- NGOs have first task effectively to achieve their development goals act like about spending their cash /companies aim to make a profit and its allocation between partners/. Moreover stipulated in the statutes of NGOs goals be publicly tracking from interested parties, and presumably are known to the public as records of NGOs are public. Set destinations organizations necessarily lawful and not contrary to good morals, otherwise they are subject to termination under the Non. The implementation of these objectives is subject to a report to the authorities themselves NGOs and annual monitoring by the state in case the NGO's selfstyled public benefit / perform community service /.

- NGOs have the right to do business under certain conditions similar to commercial companies and cooperatives, as long as their business simultaneously satisfies several conditions:

- To be connected to the main activities of NGOs;

- To be ancillary to the main activity;

- To defined explicitly in the statute / offices of NGOs; - Revenue of it be used to achieve the objectives of the statute / office purposes.

In many cases exceeded the volume of business NGOs virtually separates the work of social enterprise in their company. Characteristic of the separation of social enterprise in separate legal personality /a regulated by the Trade Law company/ is that its sole shareholder is the very NGOs. The composition of the management bodies of the corporation is determined by the NGOs, which supervises the work of those responsible and determine their powers. Thus the focus of the work of social enterprise remains in NGOs and the existence of the corporation is justified solely by the need for structural separation of the management team responsible for this. The obligatory business characteristics that can be carried out by NGOs, makes it very closely related to the nonprofit, ideal goals of the organizations - in practice it is only a means to achieve them. In this sense, when that business is done by NGOs and the organization aims to support vulnerable groups fill the criteria for social enterprise. NGOs shall not distribute profits from the business, and the resulting gain can only be used to achieve profit targets. Namely the combination of these features makes it very often in practice NGOs preferred form of support from the state to promote the social economy.

Current Bulgarian legislation provides a good basis for economic and social activities with social impact. Over 30 preferential regime, including tax and related deductions that apply in the corporate economy are directly applicable to undertakings and social economy organizations. A more precise analysis of this system of preferences warrants to offer additional incentives and to introduce profiling of such measures to the specifics of the social economy. The creation of the routine functioning mechanism for monitoring public activities with social impact, collecting and analyzing data on their condition, activity and results, as well as their needs for improving the legislative framework to maintain and stimulate their activity is immediate task inherent in the state administration, which when established necessary, in consultation with all stakeholders, will take the amendments to the regulations on businesses and social economy organizations:

- For legal recognition;

- For statistical recognition; 
- Profiling, respectively expanding the scope of the preferential arrangements for full inclusion in their subjects' social economy.

Legal and statistical recognition of enterprises and social economy organizations is an important prerequisite for clear and fair interaction between the state and the social economy. In particular, statistics on these activities will support the state for accurate orientation and development not only of policies for the social economy, but also the general policies of social protection.

National concept of social economy reflects the views of interested parties to maintain reasonable proportions in rights, duties, control and monitoring of the social economy and involvement of stakeholders in order to avoid stagnant state regulation. Economic and humanitarian activities with the characteristics of the social economy should be freely chosen by the artists themselves, including by using examples from the established European practices. The state will avoid over-regulation and control of enterprises and social economy organizations to keep their autonomy and administrative and financial distance in terms of public administration and public sector in the economy. At the same time the state will require social enterprises and organizations, which have been assigned the brand "Product of the social enterprise" to provide institutional and financial public transparency.

In Bulgarian, as in most other European legal doctrines, there are two understandings on what the work should be placed focus on defining the criteria to be met by social enterprise - that the legal form of unification, giving explicit legal form and regulation or the behavior of the entity itself. In the Bulgarian framework (yet strategic) favors not the form in which will be organized social enterprise as a subject of law and of the goals we set and what effect pursuing. It is important that the activities of the social enterprises to be directed to the provision of goods or services to disadvantaged people, the involvement of these persons in the production and provision of goods or services so as to achieve a positive social impact on society.

In accordance with timetables definition Bulgarian legislator has chosen not to regulate explicitly social enterprise as a separate legal form, outlining the capabilities of origination, management and termination and is left to the will of individuals to decide for themselves how to organize their activities in line with existing legal forms. The result is that in practice in Bulgaria social enterprises can exist as companies, cooperatives, non-profit profit / $\mathrm{NGO}$ / as long as they meet the other criteria - have important social outcomes for vulnerable groups.

\section{The practice}

The most frequently chosen form that unites people to achieve certain goals in the social sphere is a legal non-profit entity. Its status is regulated in the Law for non-profit organizations. What distinguishes non-profit goal of these alliances and possible even at the level of conceptual design, and then in the very spirit of the law is the placement of these goals. At the inception of the NGO founders combine their efforts for the realization of put their ideas and strategies to alter certain social relations in specific environments. Since the adoption of the Law for non-profit organizations and the changes to the Social Assistance Act /SAA/ the majority of NGOs perceive their mission implementation of policies in the social sector, covering the scars of social enterprise, according to the understanding of the European Commission.

In view of such underlying conditions as social can identify different in its legal status companies if their business is aimed at improving the situation of persons belonging to vulnerable groups. Therefore, to determine an entity as "social", it must have the following additional features:

Performed by the enterprise business have pronounced and lasting social impact ie activities carried out in social enterprise to pursue fundamentally and permanently in time certain social goals. It should be noted that a single provision of financial or non-financial assistance / support person from socially vulnerable group or the provision of a single service cannot be considered a work of social enterprise.

Performed by social enterprise business have a specific purpose or goal - to improve the standard of living of persons deemed by society to be vulnerable; to provide employment and create conditions for their economic independence; to provide services or other support with a view to their effective social inclusion.

Regulated financial and non-financial incentives should comply with state aid rules.

The lack of explicit legal regulation now allows social enterprise to be created under different legal forms, as long as its activities aim to achieve positive, measurable social impact rather than profit maximization. Generated profits should be reinvested primarily to achieve social objectives. If exceptionally a company distributes profits between shareholders and owners, it must be established rules and procedures so that distribution of profits does not negatively affect the primary social objective of the enterprise. Practice shows that the main forms of differentiation of social enterprises in Bulgaria are as follows: 
- Legal non-profit organizations (NGOs) that can perform direct business. It is this business have identified NGOs as a social enterprise, provided it is directed towards a particular social purpose. The Law on NGOs makes special demands on the business activity of NGOs - to be more, to be connected to the main subject of activity is regulated in the office, not to distribute profits, and if such is generated, it can be used to achieve non-profit purposes.

- Cooperatives of people with disabilities and other types of cooperatives that provide social services or goods to vulnerable, marginalized, disadvantaged or isolated; or using the method of production of goods or services, which is enshrined their social purpose.

State support to "operators" who pursue social goals and achieve socially significant results, is expressed by specific forms of financial support. Depending on incentives may have different dimensions - to express themselves in lower tax liabilities in subsidizing certain activities or easier access to credit.

Funding of social enterprises and tax regime for them

Taxes that are relevant to the activities of social enterprises are:

- Corporate tax: due to the profit realized in doing business, as well as rental of own movable and / or immovable property, whether business was conducted in Bulgaria or abroad. The tax rate is $10 \%$ on the profit for the fiscal year. The regulation contained in the Corporate Income Tax Act.

- Tax expenses: There are two types - a tax on social spending (eg social costs incurred by the social enterprise as an employer in respect of their employees) and tax on entertainment expenses. Social enterprises, whether NGOs or companies / cooperatives, subject to common grounds to excise those two types of taxes. The tax on expenses is regulated by Part 4 of the act. The tax rate in both cases was $10 \%$ on the social, entertainment expenses, respectively.

- Withholding tax: this is a final tax, which applies to income realized from the implementation of the so. Called. Indirect business, ie when the social enterprise is separated into a separate company and NGOs receive dividends or liquidation shares for participation in him. The regulation contained in the act. The tax rate is $5 \%$ on the amount of dividends received, respectively liquidation share.

- Value Added Tax: obligation accrues refers to persons performing an independent economic activity in accordance with the Law on Value Added Tax (VAT). Such under the law is any activity that occurs regularly or professionally by one person against remuneration. For such activity would therefore be considered activities of social enterprises, regardless of what legal form they exist. For the purposes of taxation provides registration before the NRA.

- Tax incentives for corporate donors include legal opportunity under the act to reduce by 10 percent its positive accounting financial result (profit), where the donations were made in favor of:

- healthcare institutions, including for therapeutic communities for drug addicts and drug addicts for their care;

- specialized enterprises or cooperatives of people with disabilities, registered under IPDA in favor of the Agency for people with disabilities, people with disabilities, as well as technical aids for them;

- NGOs registered in the Central Register of non-profit community service with the exception of organizations supporting culture within the meaning of the Law on Patronage.

- Other listed in the act.

Tax relief for donors - individuals who have made donations to the social enterprises are possible under the Law on Income Tax of Individuals. According to this law, individuals may deduct to $5 \%$ of its taxable income for donations made in favor of:

- Healthcare facilities;

- Medical institutions;

- Specialized enterprises or cooperatives of people with disabilities registered under the Integration of Persons with Disabilities and to the Agency for Persons with Disabilities;

- NGOs registered in the Central Register of Legal Entities non-profit public benefit, with the exception of organizations supporting culture within the meaning of the Law on Patronage;

- Therapeutic communities for drug addicts; 
- Other listed in the act.

- Exemption from payment of local tax donation received by NGOs - social enterprise, donations or grants provided by him to others. This relief is provided in the Act on Local Taxes and Fees (Fees Act) and may be used only if NGOs - social enterprise is registered in the public interest in the Central Register at the Ministry of Justice.

Another type of tax incentives exist only for more specialized enterprises for people with disabilities. The corporate tax is remitted entirely legal persons - specialized enterprises or cooperatives within the meaning of the Integration of Persons with Disabilities on 31 December of the year are members of the nationally representative organizations of and for people with disabilities and in which at least:

- $20 \%$ of the total number of staff are blind and partially sighted people, or

- $30 \%$ of the total number of staff are hearing impaired or

- $50 \%$ of the total number of staff are people with other disabilities.

There are also tax breaks for businesses that commit to hiring long-term unemployed. According to the tax act taxpayer is entitled to reduce their accounting financial result in the determination of the tax financial result when hired person employment for not less than 12 consecutive months at the time of his hiring it:

- Registered as unemployed for more than one year, or

- Registered unemployed person aged 50 years or

- Unemployed person with reduced capacity.

The Economic and Social Council (ESC) believes that currently provided tax incentives are insufficient to stimulate real development of social entrepreneurship in Bulgaria. Incentives exist primarily to corporate donors and to a lesser extent to donors - individuals. Such a measure encourages more corporate social responsibility. There are no significant tax incentives for the activity carried out by social enterprises, such as financial incentives policy focuses largely only to entrepreneurship as one of the vulnerable groups related to people with disabilities. The Council needs a legal framework that ensures an encouraging environment for the development of social enterprises, clearly regulate specific tax relief to all who meet the definition and the result of social enterprise, and with a view to its own activities.

"Positive" discrimination

One of the most common measures used worldwide to stimulate the social economy are measures relating to so. Pomegranate. Positive discrimination (also called "feedback"). Positive discrimination is explicitly favoring a particular group / groups of people who have been subjected to historical or persistent discrimination; the result sought is compensation for hidden discrimination and ensuring a more balanced social performance. The goal of affirmative action is to "correct" a previous injustice. In Bulgarian legislation there are various examples of positive discrimination, but connected with the activity of social enterprises as entities involved in economic turnover are provided hypotheses in some of the recent amendments to the law on public procurement. The Contracting Authority shall retain the right to participate in procedures for the procurement of specialized enterprises or cooperatives of people with disabilities when:

1. The subject of the contract is included in the list approved by the Council of Ministers, or 2. The contract runs programs to protect the employment of persons with disabilities. The contracting authority must indicate this condition in the notice of initiation of the contract.

Specialized enterprises or cooperatives of people with disabilities participate, provided they can meet at least 80 percent of the subject of the contract with its own production and resources or subcontractors who also have specialized enterprises or cooperatives of people with disabilities. Nationally representative organizations of and for people with disabilities each year to 30 September of the current year published on the Public Procurement Portal information about the capacities of their members.

Also contracting authority found the following calendar year tender in order of when it can be performed by specialized enterprises or cooperatives of people with disabilities.

When after the said procedure was not selected contractor, the contracting authority may open a new procedure, without the right of participation of specialized enterprises or cooperatives of people with disabilities. Entity shall specify in the decision to initiate the reasons for the termination of the previous procedure (Petkova, 2008, Petkova, 2009; Petkova - Georgieva, Yanakieva, 2012; Petkova, Strateva, 2012a; Petkova, Tasheva, Petkov, 2018b-c). 
Proposals to change the legislation formulated by BCAF and BCNL

In order to provide a better framework for the development of social enterprises in Bulgaria Foundation "Charities Aid Bulgaria" foundation "Bulgarian Center for Non-profil Law" make proposals (2019i) to the Interagency Working Group on Social Economy, stressing that it is important to be on the discuss these important issues before proceeding to the painting of concrete legislative texts aimed at regulating social entrepreneurship:

- Regulating the level of law key elements that define a business as a "social enterprise" which regulate in turn should have a single purpose - conducting a clear policy of the state, promoting growth and prosperity of social enterprises, and from there and their users. The introduction of a legal framework for social enterprises should include concrete measures to promote their development at national and local level to justify the introduction of regulations. This direction of reforms is advocated by the European Commission, clearly stated that the first need is financial support, followed by clear and simple rules, including the reduction of administrative and regulatory burden as a whole.

- Taking into account the above-mentioned notes, and practice that has developed in Bulgaria during the last 10 years in terms of the profile of social enterprises, we support the idea of regulating the level of law the main characteristics to determine a business as a social enterprise with the above objectives - provide support by holding a consistent policy to promote their business. Next, this provision should be provided in parallel with the following measures:

- Proclaims schemes for financial assistance to start-up social enterprises and those that are in the early stages of its development, regardless of the legal form in which they exist;

- Reducing administrative regulatory burdens on organizations wishing to develop social entrepreneurship;

- Ensuring equal opportunities for all private providers of public services;

- Universalization of tax incentives and exemptions for employers of people from vulnerable groups to social enterprises, regardless of their legal form.

- It is the formation of a separate legal form of social enterprise since currently Bulgarian legislation through the Commerce Act, the Cooperatives Act and the legal non-profit provides ample opportunities for association of persons and achieve societal goals. More important here is to create conditions for development of their activities to achieve added value towards social inclusion of various vulnerable groups.

- The future legal regulation should include specific criteria that reflect the following principles:

Independence and autonomy of the establishment (creation and management is the result of an independent decision of the founders, is not due to the implementation of the decision of the supreme national or local level);

Presence of socially useful purposes (the primary purpose of which is created now is not to make profits but to meet the demands and needs of people from vulnerable groups, environmental or other socially significant goals - social inclusion, solidarity, antidiscrimination, etc., i. e. its main purpose is to solve a problem that is important for the whole society);

The enterprise is expressed in 1) manufacturing and / or supplying goods and services in favor of and focused on meeting the needs of people from vulnerable groups (eg social services, educational services and the like) and / or 2) aimed at solving social issues (such as environmental protection, preservation of cultural heritage and so on..) and / or 3) now permanently (and not sporadically) engages in economic activity on a market basis, through which and within which provides permanent employment for people from vulnerable groups;

Revenue and profits of the parent company (after settlement of losses) are advantageously used to achieve the main profit and socially useful social purpose, which is guaranteed by the inner organizational rules of the legal entity or guaranteed by law;

The distribution of profits is prohibited or restricted by law (for NGOs - it will be NPLEA, but for others - limit profit distribution must be law NAO).

- Simultaneous with this regulation should be introduced following a specific stimulus package:

- To regulate various tax breaks when operating as a social enterprise or implementation of the services / goods produced within this activity; 
- To create easier access and procedures for the participation of social enterprises as contractors of public works - widening the circle of persons under the current Public Procurement Act / PPA /;

Develop awareness simplified procedures for employers' social enterprises - what documents should prepare by hiring disadvantaged people (people with disabilities, long-term unemployed, people at high risk of unemployment, etc.) in order to avoid the administrative burden of employers and subsequent sanctions by the Executive Agency "General Labour Inspectorate".

To develop more measures aimed at promoting and supporting the activities of social enterprises in order to build capacity and competitiveness and development of innovations. Funding for these measures may be part of the operational programs, but also to ensure sustainability - should universalize national mechanisms to support small and medium enterprises and open and social enterprises (regardless of their legal form).

- Reduce the time and deadlines for all registration and licensing regimes;

- To establish a mechanism and methods in which to collect statistical information about the social enterprises, the process of their development, and for assessing the impact of their activities.

- Operational programs and creating new horizons of European investment - European Social Fund announced that in the new programming period, social enterprises and social entrepreneurship will be a priority. To actually be supported should be prepared adequate and real incentives for the development of social entrepreneurship, which include:

Limit the application of state aid rules, reflected in Regulation 651/2014;

Reduce the administrative burden for managing and reporting on projects (eg by introducing an electronic system similar to PADOR when applying for funding under the different mechanisms and incentives);

Development of independent measures for operations under the OP Human Resources Development since 2015. Which are aimed at social enterprises and social entrepreneurship (in the indicative program for 2015 does not include such measures);

Innovation and Competitiveness OP also be measures that are aimed at social enterprises in their various legal forms, given their role in the discovery and application of innovation in certain economic sectors.

- To facilitate access to finance for social enterprises at the start of their activities, their development and expansion through investments in social investment funds that provide equity instruments and debt financing.

According importing the proposal provides only a certain legal framework (definition of social enterprise) without appropriate measures that make it a policy to support and develop, not only fail to achieve the objectives of the National concept of social economy, but in practice will become a mechanism for regulations that will prove unnecessary, and possibly be a "super regulator", and hence limiting (Stoeva, 2016b-c; Arabska, 2016d; Ovcharova, 2017-a; Terziev, Nichev, Georgiev, 2019f-g).

\section{CONCLUSION}

In the National concept of social economy following recommendations are made in connection with the development of regulations (2019j):

Need for ongoing improvement of legislation as a precondition essential for activity, stabilization and development of enterprises and social economy organi-zations.

Conduct ongoing due diligence in aspects of the social economy in order to develop relevant legislative changes, as well as individual acts aimed at harmoniz-ing and developing the existing legal framework.

\section{REFERENCE LIST}

Terziyev, Venelin. (2019). Sotsial'naya ekonomika i sotsial'noye predprinimatel'stvo. // Sovremennyy menedzhment: problemy i perspektivy: sbornik statey po itogam XIV mezhdunarodnoy nauchnoprakticheskoy konferentsii «Sovremennyy menedzhment: problemy i perspektivy» 25-26 aprelya 2019 goda, Ministerstvo nauki i vysshego obrazovaniya Rossiyskoy federatsii, Izdatel'stvo SanktPeterburgskogo gosudarstvennogo ekonomicheskogo universiteta, Sankt-Peterburg, Rossiya, 2019, s. 412-435, ISBN 978-5-7310-4567-4 (Терзиев, Венелин. Социальная экономика и социальное 
IJASOS- International E-Journal of Advances in Social Sciences, Vol. V, Issue 14, August 2019

предпринимательство. // Современный менеджмент: проблемы и перспективы: сборник статей по итогам XIV международной научно-практической конференции «Современный менеджмент: проблемы и перспективы» 25-26 апреля 2019 года, Министерство науки и высшего образования Российской федерации, Издательство Санкт-Петербургского государственного экономического университета, Санкт-Петербург, Россия, 2019, с. 412-435, ISBN 978-5-73104567-4).

Terziev, V, Bencheva, N. (2019a). Current status of social entrepreneurship in Bulgaria. // Advances in Bulgarian science'2018, National centre for information and documentation (NACID), Sofia, 2019, pp.5-18, ISSN 1314-3565.

Bencheva, N., Stoeva, T., Todorova, S. (2018). Key Skills and Competences for Social Business Advisors: Views from Experts, International Journal of Organizational Leadership, 7(2018), pp.413-425; ISSN 2383-1103 (Print); ISSN 2345-6744 (Online).

Bencheva, N., Tepavicharova, M. (2016). Support structures for social entrepreneurship in Bulgaria, The first scientific conference on social entrepreneurship on "Tips, skills and tools for consulting social entrepreneurs", pp.29-35, ISBN 978-954-517-249-6 ISBN 978-954-517-250-2.

Tepavicharova, M., Bencheva, N. (2016a), Factors for development of the educational and professional qualitication profile of the managers from the services sector in Bulgaria, Scientific journal «Economics and Finance», Science and Practice, Conference proceedings, Citation Index - Social Sciences \& Humanities (CPCI-SSH), Thorpe-Bowker, Melbourne, Australia, pp.42-47, ISBN 978-0-9942661-3-2.

Bogdanova, Margarita. (2018a). Policies and Instruments for Social Development. Journal of Innovations and Sustainability, Plovdiv, Bulgaria, 4, 2018, 1, pp. 59-63, ISSN 2367-8127 (CD-ROM), ISSN 23678151 (ON-LINE).

Petkova, St., (2008). Balanced scorecard as instrument of strategic controlling, Forum Gesundheit und Soziales, Beitrage aus Lehre, Forschung und Praxis der Studiengange der Evangelischen Fachhochschule Berlin, Heft 6, p.60-68, ISSN 1863-1851, Berlin, 2008.

Petkova, St. (2009). Tendentsii za upravlyavane na strategicheskiya risk s pomoshtta na balansirani sistemi ot pokazateli, Godishnik na MGU „Sveti Ivan Rilski”, tom 52, str.87-91, ISSN 1312-1820, Sofiya, 2009 (Петкова, Ст., Тенденции за управляване на стратегическия риск с помощта на балансирани системи от показатели, Годишник на МГУ „Свети Иван Рилски”, том 52, стр.87-91, ISSN 13121820, София, 2009).

Petkova - Georgieva, St., A., Yanakieva, (2012). Balansiranata sistema ot pokazateli kato savremenen metod na upravlenie $v$ turisticheskoto predpriyatie, akademichno spisanie "Upravlenie i obrazovanie", tom VIII, kn. 1, str.140-144, ISSN 13126121, Burgas, 2012. (Петкова - Георгиева, Ст., А., Янакиева, Балансираната система от показатели като съвременен метод на управление в туристическото предприятие, академично списание “Управление и образование”, том VIII, кH. 1, стр.140-144, ISSN 13126121, Бургас, 2012).

Petkova, St., Iv. Strateva, (2012a). Opredelyaneto na strategicheskite vrazki po deynosti kato klyuchov podhod v kontrolinga, godishnik na Universitet "Prof. d-r Asen Zlatarov", Br. XLI, kn. 2, str.106-112, ISSN 1312-1359, Burgas, 2012 (Петкова, Ст., Ив. Стратева, Определянето на стратегическите връзки по дейности като ключов подход в контролинга, годишник на Университет “Проф. д-р Асен Златаров", Бр. XLI, кн. 2, стр.106-112, ISSN 1312-1359, Бургас, 2012).

Petkova, S., Tasheva, Y., P. Petkov, (2018b). Assessment of the Pyrolytic Fractions from Refused - Derived Fuel, Oxidation Communications, p. 462 - 467, book 41, vol. 3, ISSN 0209-4541, 2018.

Petkova, S., Tasheva, Y., P. Petkov, (2018c). Evaluation of Possibility to Use Liquid Pyrolysis Fractions as Fuel, Oxidation Communications, p. 468 - 474, book 41, vol. 3, ISSN 0209-4541, 2018.

Terziev, Venelin. (2019b). Social policy and labor market development in Bulgarian transition period. INTCESS 2019- 6th International Conference on Education and Social Sciences, 4-6 February, 2019, Dubai, International Organization Center of Academic Research, 2019, pp. 703-714, ISBN: 978-60582433-5-4.

Terziev, Venelin. (2019c). Theoretical basis of development of labor market and social policy in the republic of Bulgaria. INTCESS 2019- 6th International Conference on Education and Social Sciences, 4-6 February, 2019, Dubai, International Organization Center of Academic Research, 2019, pp. 715-726, ISBN: 978-605-82433-5-4. 
IJASOS- International E-Journal of Advances in Social Sciences, Vol. V, Issue 14, August 2019

Terziev, V., Bekiarova, N., Georgiev, M. (2019d). Support structures for the development of social entrepreneurship. // KNOWLEDGE - Capital of the future, International Journal Scientific Papers Vol. 29.1, February, 2019, Institute of knowledge management - Skopje, Macedonia, 29, 2019, N 1, pp. 21-25, ISSN 1857-923X (for e-version), ISSN 2545 - 4439 (for printed version).

Bencheva, N., Stoeva, T. (2019e). The role of management skills in social entrepreneurship: expert assessment. // 20th International conference - Knowledge without borders, Vrnjacka Banja, Serbia (29-31.03.2019), Institute of knowledge management - Skopje, Macedonia, 30, 2019, N 6, pp. 15931597, ISSN 1857-923X (for e-version), ISSN 2545 - 4439 (for printed version).

Stoeva, Teodora. (2016b). Predizvikatelstva i potrebnosti ot obucheniya na sotsialnite biznes konsultanti. // Parva nauchna konferentsiya po sotsialno predpriemachestvo. Saveti, umeniya i instrumenti za konsultirane na sotsialnite predpriemachi. Agraren Universitet Plovdiv, 2016, str. 71 -74 (Стоева, Теодора. Предизвикателства и потребности от обучения на социалните бизнес консултанти. // Първа научна конференция по социално предприемачество. Съвети, умения и инструменти за консултиране на социалните предприемачи. Аграрен Университет Пловдив, 2016, стр. 71-74).

Stoeva, Teodora. (2016c). Sotsialni deynosti v obshtina Plovdiv. // Parva nauchna konferentsiya po sotsialno predpriemachestvo. Saveti, umeniya i instrumenti za konsultirane na sotsialnite predpriemachi. Agraren Universitet Plovdiv, 2016, str. 111-117 (Стоева, Теодора. Социални дейности в община Пловдив. // Първа научна конференция по социално предприемачество. Съвети, умения и инструменти за консултиране на социалните предприемачи. Аграрен Университет Пловдив, 2016, стр. 111-117).

Arabska, Ekaterina.(2016d). Iziskvaniya za umeniya ot konsultantite za osiguryavane na efektivna podkrepa na sotsialnite predpriyatiya. // Parva nauchna konferentsiya po sotsialno predpriemachestvo. Saveti, umeniya i instrumenti za konsultirane na sotsialnite predpriemachi. Agraren Universitet Plovdiv, 2016, str. 75-81 (Арабска, Екатерина. Изисквания за умения от консултантите за осигуряване на ефективна подкрепа на социалните предприятия. // Първа научна конференция по социално предприемачество. Съвети, умения и инструменти за консултиране на социалните предприемачи. Аграрен Университет Пловдив, 2016, стр. 75-81).

Ovcharova, S. (2017). Motivation in knowledge economy. // 6th International congress Knowledge Economy \& Management, 26-28.12.2007, Istanbul, Turkey, 2017, pp.1643-1651. ISSN: 1308-3937.

Ovcharova, S. (2017a). Knowledge management in some Bulgarian organizations. // 6th International congress Knowledge Economy \& Management, 26-28. 12.2007, Istanbul, Turkey, 2017, pp.19081915. ISSN 1308-3937.

Terziev, V., Nichev, N., Georgiev, M. (2019f). Current status of social entrepreneurship: social enterprises and state. // 20th International conference - Knowledge without borders, Vrnjacka Banja, Serbia (2931.03.2019), Institute of knowledge management - Skopje, Macedonia, 30, 2019, N 6, pp. 1587-1591, ISSN 1857-923X (for e-version), ISSN 2545 - 4439 (for printed version).

Terziev, V., Nichev, N., Georgiev, M. (2019g). Social enterprises and their impact in Bulgaria. // 20th International conference - Knowledge without borders, Vrnjacka Banja, Serbia (29-31.03.2019), Institute of knowledge management - Skopje, Macedonia, 30, 2019, N 6, pp. 1645-1649, ISSN 1857923X (for e-version), ISSN 2545 - 4439 (for printed version).

https://eur-lex.europa.eu/homepage.html (2019h).

http://bcaf.bg/bg/aktualno/position/750-predlovenia-za-promyana-v-zakonodatelstvoto-sp.html/, (2019i).

https://www.mlsp.government.bg/, (2019j). 